\section{Predicting Hollow Heart Incidence in Triploid Watermelon (Citrullus lanatus)}

\author{
Marlee A. Trandel and Penelope Perkins-Veazie
}

Department of Horticultural Sciences, Plants for Human Health Institute, North Carolina State University, 600 Laureate Way, Kannapolis, NC 28081

\author{
Jonathan Schultheis \\ Department of Horticultural Sciences, North Carolina State University, 2721 \\ Founders Drive, 264 Kilgore Hall, Raleigh, NC 27695
}

Additional index words. cucurbit, internal defect, pollination, cultigen, seedless

Abstract. In triploid (seedless) watermelon [Citrullus lanatus var. lanatus (Thunb. Matsum. and Nakai)], hollow heart (HH) is a disorder that is expressed as a crack in the center of the fruit that expands to an open cavity. Although $\mathrm{HH}$ incidence and severity is part of a screening process for marketable watermelon fruit during cultigen evaluations, HH incidence is highly variable with growing season, even when the best cultural practices are used. Placental tissue firmness is also measured because firmness is related to the marketability of watermelon and may be related to HH. Genetic and environmental factors can influence watermelon $\mathrm{HH}$ development, including plant genetics, pollen amount and viability, pollinator activity, and temperature and rainfall fluctuations. We used seedless watermelon cultigen evaluation data collected over 3 years (2012-14) to determine the relationship between germplasm $\mathrm{HH}$ and tissue firmness. Transplanted watermelon representing 30 to 44 cultigens per year were grown at the Central Crops Research Station, Clayton, NC, and interplanted with pollenizers 'Ace' and/or 'SP-6'. Harvested fruit were cut length-wise and rated for $\mathrm{HH}$ incidence and severity. Flesh firmness was determined by a handheld penetrometer at five locations in the flesh (stem end, top side, ground spot, blossom end, and heart). A common cultigen subset, consisting of 13 cultigens that were grown in all three experiments, was used for analysis of $\mathrm{HH}$ severity and incidence, and placental firmness. The presence of $\mathrm{HH}$ was negatively correlated with tissue firmness in both the large multiyear cultigen set $\left(R^{2}=-0.32 ; P=0.0001\right)$ and the common cultigen set $\left(R^{2}=-0.78 ; P=0.0001\right)$. Cultigens with lower watermelon tissue firmness values had higher $\mathrm{HH}$ incidence and severity. By using multiyear cultigen studies and logistic regression, we were able to detect trends for cultigen susceptibility to this highly variable disorder. Using logistic regression, the probability of HH development was highest for 'Bold Ruler', 'Liberty', and 'Affirmed', and lowest for 'Maxima' and 'Captivation'. The identification of cultigens with a tendency for higher or lower rates of $\mathbf{H H}$ will be useful for further research of the causes of $\mathrm{HH}$. Measurements of placental flesh firmness may be useful indicators of susceptible cultigens.
Globally, watermelon is the largest produced fruit crop (Tlili et al., 2011), with18.1 MT produced in 2018 (USDA, 2019). In the United States, seedless (triploid) watermelon comprises $90 \%$ to $95 \%$ of the market (USDA, 2019). One of the United States Department of Agriculture (USDA) grade defects in triploid watermelon is the appearance of hollow heart $(\mathrm{HH})$, which is also known as internal cracking (USDA, 2006). In watermelon, HH occurs as an internal split or void that usually starts in the placental (heart) tissue and can extend through the carpels into the epidermal (rind) layers

Received for publication 11 Aug. 2020. Accepted for publication 22 Sept. 2020.

Published online 22 October 2020

We thank Joy Smith for help with statistical analysis.

M.A.T. is the corresponding author. E-mail: matrande@ncsu.edu.

This is an open access article distributed under the CC BY-NC-ND license (https://creativecommons. org/licenses/by-nc-nd/4.0/). tissues (Kano, 1993), and it most often occurs in fruit from the crown set (or first harvested fruit) (Diezma-Iglesias et al., 2004). The watermelon rind continues to expand and differentiate during fruit growth and maturation. Placental tissue cells stop dividing at $7 \mathrm{~d}$ after anthesis, and cells begin to enlarge with the accumulation of water, sugars, proteins, and nutrients (Elmstrom and Davis, 1981; Kano, 1993). A rapid change in water potential between placental cells and rind cells can lead to a separation of the carpels, ovule tissue, and placental tissue, causing hollowing or a cavity to develop in the flesh (Johnson, 2014, 2015; Kano, 1993).

Inadequate pollination is thought to be one of the leading causes of $\mathrm{HH}$ in watermelon and is generally worse in triploid (seedless) watermelons because they require a diploid (seeded) pollenizer with viable pollen (Diezma-Iglesias et al., 2004). Inadequate pollination can come from an improper diploid pollenizer-triploid combination (McGregor and Waters, 2014), reduced bee visits, or unfavorable weather conditions (e.g., decrease in pollen viability and/or pollinator activity) (Pisanty et al., 2016). Additionally, cytokinins known to promote cell division can affect watermelon flesh firmness and cell density (Soteriou et al., 2017) and may contribute to inadequate pollination.

Previous studies have reported that watermelon fruit from plantings with lower diploidto-triploid ratios have a higher incidence of $\mathrm{HH}$ (Fiacchino and Walters, 2003; Freeman et al., 2007). Generally, any diploid-to-triploid ratio less than $20 \%$ of a field (e.g., four triploids to one interplanted diploid pollenizer) increases $\mathrm{HH}$ formation (Freeman et al., 2007). To achieve optimal fruit yields and high watermelon fruit quality, $25 \%$ to $33 \%$ of a field should be planted with diploid plants (Fiacchino and Walters, 2003; Freeman and Olson, 2007a). This is achieved by interplanting a seeded watermelon cultigen or diploid pollenizer in the same field either in the same row as triploid plants or as a dedicated row only for diploid pollenizers (Freeman et al., 2007). incidence is highly variable, even when planted at the same geographic location (Seminis Seeds, 2019), which increases the difficulty screening germplasms for the disorder. The relationship between watermelon fruit firmness
In watermelon cultigen evaluations, the $\mathrm{HH}$

It is thought that $\mathrm{HH}$ develops as a result of unequal expansion of placental and rind

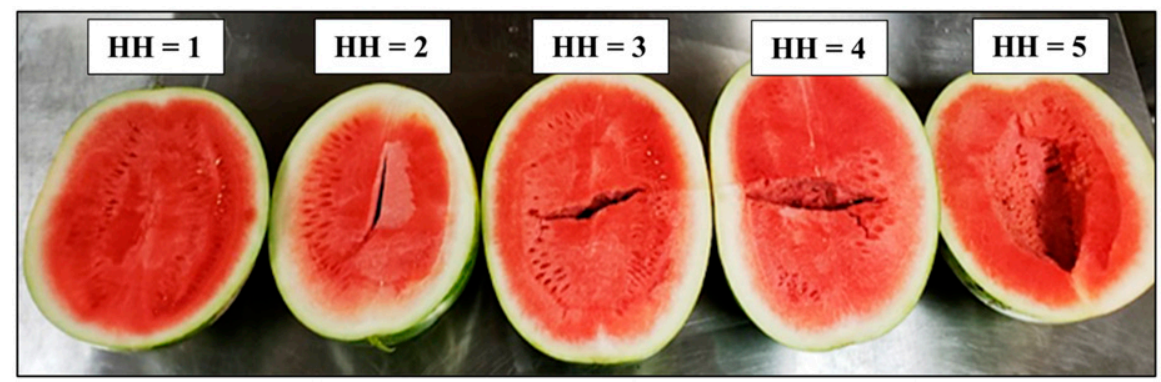

Fig. 1. Hollow heart rated using a scale of 1 to $5(1=$ no or very minor $\mathrm{HH} ; 5=$ severe $)$. Fruit with moderate to severe levels of $\mathrm{HH}$ (rated 2 to 5 in severity) do not meet the U.S. Department of Agriculture (USDA) grade for watermelon marketability. 
and the incidence of $\mathrm{HH}$ has not been studied, although researchers have suggested fruit tissue firmness may provide some indication of $\mathrm{HH}$ disorder (Guan, 2018). Cultigen evaluations for watermelon productivity and fruit traits are routinely conducted across the United States (Coolong, 2015; Johnson, 2017; Schultheis and Thompson, 2014). Fruit firmness and HH incidence are collected as part of these evaluations in North Carolina, resulting in datasets that might be useful for detecting relationships. Therefore, in this study, 3 years of seedless watermelon cultigen evaluation data were used to determine possible germplasm trends for high and low $\mathrm{HH}$ incidences and tissue firmness.

\section{Materials and Methods}

Experimental site. The three watermelon cultigen evaluations were conducted during a field experiment at the Central Crops Research Station (lat. $35.6507^{\circ} \mathrm{N}$, long. $-78.4962^{\circ} \mathrm{W}$ ) located in Clayton, NC (North Carolina State University) from May to September in 2012, 2013, and 2014. The soil type was sandy clay loam $[80 \%$ sand, 5\% clay, low organic matter (1\% to $1.5 \%)$, and low acid retention] (Kleiss, 1981). The average maximum and minimum temperatures, rainfall, and cumulative rainfall for May to September in 2012, 2013, and 2014 are provided in Table 1. Day and night temperatures and daily rainfall during peak pollination and fruit set (3-6 weeks after transplanting) are reported in Fig. 2.

Experimental design and treatments. A randomized complete block design (RCBD) with four replications was used for each watermelon cultigen evaluation in 2012, 2013, and 2014, with five fruit randomly collected from each plot (20 fruit/entry) used as the experimental unit for evaluations. New seed were obtained each year and consisted of 44, 40, and 30 entries for 2012, 2013, and 2014, respectively. Additionally, the common cultigen data set includes the 13 common cultigens that were included in all 3 years. The common cultigens and fruit characteristics are listed in Supplemental Table 1.

Seedling and field preparation. Seed of triploid cultigens and diploid pollenizer plants were sown 5 Apr. 2012, 5 Apr. 2013, and 15 Apr., 2014. Seeds were sown into polythylene transplant trays (Hummert International, Earth City, MO) filled with commercial soilless mix (Fine Germinating Mix; Carolina Greenhouse and Soil Company, Kinston, NC) and held under greenhouse conditions (range, 24 to $30{ }^{\circ} \mathrm{C}$ ). Approximately 3 weeks after seeding, watermelon transplants were placed in either a coldframe or a high tunnel to harden. Transplants were field-planted 8 May 2012, 14 May 2013, and 19 May 2014. Granular fertilizer was the same for each year and applied at $33.6 \mathrm{~kg} \cdot \mathrm{ha}^{-1}$ $\mathrm{N}$ and $74.1 \mathrm{~kg} \cdot \mathrm{ha}^{-1} \mathrm{~K}$. Granular fertilizers were incorporated into the beds before laying black polyethylene plastic $(0.70-\mathrm{mm}$-thick high-density plastic film, $1.2 \mathrm{~m}$ wide; B.B. Hobbs, Clinton, NC).

The study fields were fumigated with Telone C-17 (Dow AgroSciences, Indianapolis, IN) via broadcast application at $93.4 \mathrm{~kg} \cdot \mathrm{ha}^{-1}$ on 14 Nov. 2011, and the same rate was applied on 9 Nov. 2012 and 7 Nov. 2013. Ethalfluralin (4.7 $\left.\mathrm{kg} \cdot \mathrm{ha}^{-1}\right), \quad \mathrm{N}, \mathrm{N}^{\prime}$-dimethyl-4,4' -bipyridinium dichloride $\left(3.5 \mathrm{~kg} \cdot \mathrm{ha}^{-1}\right)$ and bensulide $(5.8$ $\mathrm{kg} \cdot \mathrm{ha}^{-1}$ ) (Dow AgroSciences) were applied between plastic beds for weed control in May (before planting) and June (before watermelon started to vine out) for all triploid watermelon evaluations (Schultheis and Thompson, 2012, 2013, 2014).

Crop production. Spacing between rows was $3.1 \mathrm{~m}$, with in-row plant spacing of $0.8 \mathrm{~m}$. Plots were one row and $7.6 \mathrm{~m}$ long, allowing 10 plants to be grown for each experimental unit. A 3.1-m alley was maintained between plots. At the time of transplantation, $20-20-20$ liquid fertilizer $(20.0 \mathrm{~N}-$ 8.7P-16.5K, Peters Professional General Purpose Fertilizer; ICL Specialty Fertilizers, Summerville, SC) and Coragen (DuPont, Wilmington, DE) were applied at 0.01 $\mathrm{kg} \cdot \mathrm{ha}^{-1}$ and $0.07 \mathrm{~kg} \cdot \mathrm{ha}^{-1}$, respectively. Plots with missing transplants were replanted $\approx 7 \mathrm{~d}$ after planting to achieve a $100 \%$ stand count for all three experiments (Schultheis and Thompson, 2012, 2013, 2014).

Pollenizer plants. During the 2012 growing season, the diploid pollenizer 'Ace' was interplanted after triploid plants 1,4 , and 7 in each plot. In 2013, two pollenizer cultigens ('Ace' and 'SP-6') were used, with 'SP-6' interplanted after triploid plants 1 and 10 , and 'Ace' was interplanted after triploid plants 4 and 7. 'SP-6' was used as the sole pollenizer source in 2014; it was interplanted after plants $1,4,8$, and 10 .

Trickle irrigation (NETAFIM, $197 \mathrm{~mL}$, $1.09 \times 10^{3} \mathrm{~mL} \cdot \mathrm{h}^{-1} ;$ NETAFIM, Tel Aviv, Israel) was used over the course of each growing season. Fertigation was started 2 weeks after planting and was drip-applied weekly over the course of the growing seasons using a $4-0-8(4.0 \mathrm{~N}-0.0 \mathrm{P}-6.6 \mathrm{~K})$ liquid fertilizer (Harrell's Max Potassium plus Calcium; Harrell's Inc., Lakeland, FL). Cumulative amounts of liquid fertilizer applied throughout the growing seasons were 102.2 $\mathrm{kg} \cdot \mathrm{ha}^{-1} \mathrm{~N}, 0.0 \mathrm{~kg} \cdot \mathrm{ha}^{-1} \mathrm{P}$, and $166.9 \mathrm{~kg} \cdot \mathrm{ha}^{-1} \mathrm{~K}$.

A conventional spray program for North Carolina was used for watermelon crop production (Schultheis and Thompson, 2012,
2013, 2014). Insecticide, fungicide, and/or miticide applications were applied every week starting from the first week of June through the second week of August. The products were alternated during consecutive spray applications among the evaluations to avoid pest resistance. Acramite (Arysta, Tokyo, Japan), a miticide, was applied in 2012; the fungicide and insecticide programs used during each of the growing seasons are listed in Supplemental Table 2.

Crop harvest and data collection. Four watermelon harvests were performed in 2012 and 2014, and five harvests were performed in 2013. The first harvests were performed on 17 July 2012, 18 July 2013, and 24 July 2014. The fruit were harvested at $\approx 65 \mathrm{~d}$ after anthesis when ripe, weighed, and rated for the incidence and severity of $\mathrm{HH}$. Using a scale of 0 to 4 , $\mathrm{HH}$ was rated in 2012; 0 indicated no $\mathrm{HH}, 1$ indicated slight $\mathrm{HH}$, and 4 indicated severe HH. During the 2013 and 2014 evaluations, a scale of 1 to 5 was used; 1 indicated no $\mathrm{HH}, 2$ indicated slight $\mathrm{HH}$, and 5 indicated severe $\mathrm{HH}$ (USDA, 2006). For uniform comparisons across years, HH ratings for 2012 were converted to a scale of 1 to 5. Other evaluations for each entry included yield, fruit shape and size, rind pattern, occurrence of hard seeds, flesh color, and soluble solids content (NC State Extension website, https://cucurbits.ces.ncsu.edu/growing-cucurbits/variety-trials/).

Flesh firmness in pounds was determined using a Penetrometer FT 011 (range, 1-11 lb/ 4.4-44 N) with a 1.11-cm-diameter plunger tip (QA Supplies LLC, Norfolk, VA). Firmness readings were taken at five locations in the placental material (flesh) (Fig. 3) at the ground spot side, opposite (top) side, blossom end, stem end, and heart; they are presented as means for 20 fruit per cultigen per year, primarily from the first or second harvests. Fruit firmness readings were converted from pounds to Newtons.

Data analysis. All statistical analyses of $\mathrm{HH}$ percent (incidence), severity, and tissue firmness were conducted using SAS 9.4 (SAS Institute, Cary, NC). The large multiyear dataset was analyzed by year because each year had a large number of cultigens not included in the other years. Data for the 13 common cultigens were analyzed by year and across the years. Linear regression was used to determine if there was a linear relationship between tissue firmness and incidence of $\mathrm{HH}$. Coefficient of determination $\left(R^{2}\right)$ values were also used to assess the relationship between tissue firmness and incidence of $\mathrm{HH}$. An analysis of variance (ANOVA) was used to quantify cultigen differences in tissue

Table 1. Average day and night temperatures, minimum and maximum temperatures, and average daily and cumulative rainfall for each cultigen evaluation year from May to September.

\begin{tabular}{lcccccc}
\hline Growing season & Day temp. $\left({ }^{\circ} \mathrm{C}\right)$ & Night temp. $\left({ }^{\circ} \mathrm{C}\right)$ & Max temp. $\left({ }^{\circ} \mathrm{C}\right)$ & Min temp. $\left({ }^{\circ} \mathrm{C}\right)$ & Rainfall $(\mathrm{cm})$ & Cumulative rainfall $(\mathrm{cm})$ \\
\hline 2012 & 29.7 & 19.5 & 39.7 & 10.6 & 0.25 & 31.5 \\
2013 & 28.9 & 19.5 & 35.1 & 11.0 & 1.19 & 131.8 \\
2014 & 29.5 & 19.3 & 35.1 & 8.6 & 0.38 & 42.5 \\
\hline
\end{tabular}




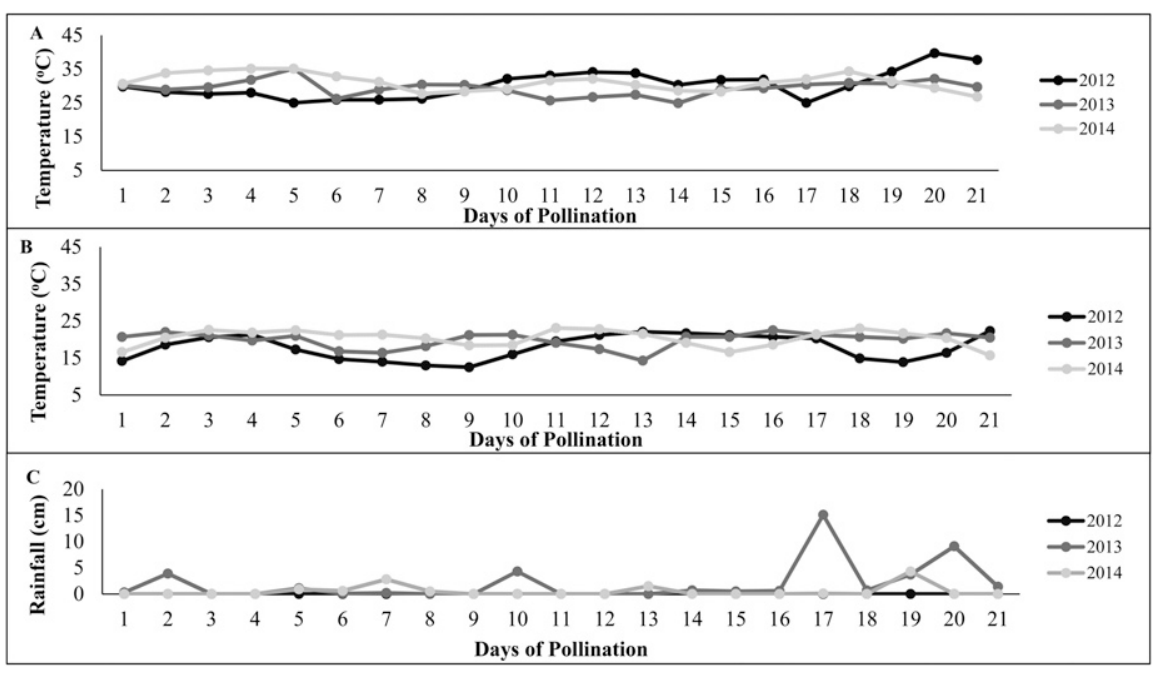

Fig. 2. Maximum (A) and minimum (B) temperatures and daily rainfall $(\mathbf{C})$ recorded during the estimated time of fruit set (3-6 weeks after transplanting) among the 2012, 2013, and 2014 triploid watermelon evaluations. The $\mathrm{x}$-axis represents the estimated number of days of pollination. In 2012, diploid flowers opened on $\approx 8$ June (climate data shown from 8 June to 1 July). In 2013, diploid flowers opened on $\approx 9$ June (climate data shown from 9 June to 2 July). In 2014, diploid flowers opened and pollination occurred on $\approx 15$ June (climate data shown from 15 June to 7 July).

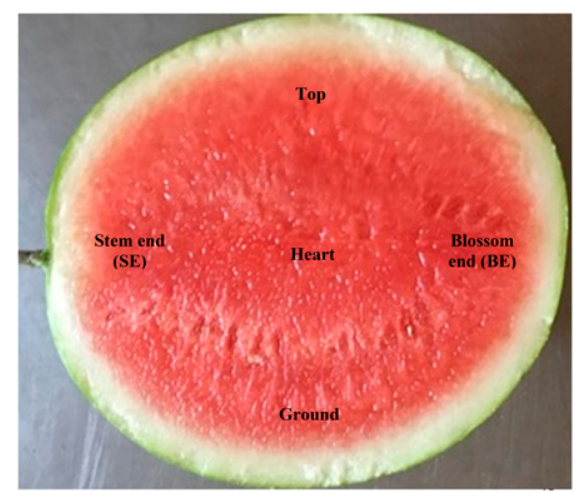

Fig. 3. Location of firmness readings taken from longitudinally cut triploid watermelon.

firmness and $\mathrm{HH}$ severity. Logistic regression was used to evaluate the incidence of $\mathrm{HH}$ $(\mathrm{HH} \%)$ and calculate cultigen predictive odds ratios for exhibiting $\mathrm{HH}$ when compared with 'Maxima'. Mean separations were performed using the Tukey-Kramer honestly significant difference test $(P \leq 0.05)$ for average tissue firmness $(\mathrm{N})$, average $\mathrm{HH}$ severity rating, and $\mathrm{HH}$ incidence among the large multiyear cultigen evaluations and common cultigens.

\section{Results and Discussion}

Incidence and severity of $H H$. Logistic regression indicated that the incidence of $\mathrm{HH}$ did not differ by year during the large multiyear cultigen evaluation (Supplemental Table 3) $(P>0.05)$. Within years, the range of $\mathrm{HH}$ incidence was highest in $2012(0 \%$ to $65 \%)$, lowest in $2013(0 \%$ to $35 \%)$, and intermediate in 2014 (0\% to 50\%) (Supplemental Fig. 1). During the large multiyear
Table 2. Incidence of hollow heart $(\mathrm{HH})$ and predictive odds of a cultigen in the common cultigen data set for developing hollow heart in any given year.

\begin{tabular}{lcc}
\hline Cultigen & HH incidence $(\%)^{\mathrm{z}}$ Predictive odds $^{\mathrm{y}}$ \\
\hline Bold Ruler & $39.3 \mathrm{a}$ & $7.0 \mathrm{a}$ \\
Liberty & $39.1 \mathrm{a}$ & $6.9 \mathrm{a}$ \\
Affirmed & $33.7 \mathrm{ab}$ & $5.5 \mathrm{ab}$ \\
Declaration & $30.5 \mathrm{abc}$ & $4.8 \mathrm{ab}$ \\
Tri-X-313 & $25.4 \mathrm{abcd}$ & $3.7 \mathrm{ab}$ \\
Fascination & $22.2 \mathrm{bcde}$ & $3.1 \mathrm{ab}$ \\
Secretariat & $19.5 \mathrm{bcde}$ & $2.6 \mathrm{ab}$ \\
ACX 6177 & $18.8 \mathrm{bcde}$ & $2.5 \mathrm{ab}$ \\
7197 & $14.4 \mathrm{cde}$ & $2.5 \mathrm{ab}$ \\
SV0241WA & $12.6 \mathrm{de}$ & $1.6 \mathrm{ab}$ \\
Crunchy Red & $11.2 \mathrm{de}$ & $1.3 \mathrm{ab}$ \\
Maxima & $8.4 \mathrm{e}$ & $1.0 \mathrm{a}$ \\
Captivation & $4.0 \mathrm{e}$ & $0.4 \mathrm{a}$ \\
$P$ value & 0.0093 & 0.0093
\end{tabular}

${ }_{\mathrm{z}}^{\mathrm{LS}}$ means of HH incidence were separated by the Tukey-Kramer honestly significant difference test $(P \leq 0.05)$. Dissimilar letters indicate significance between cultigens.

${ }^{\mathrm{y}}$ Odds of developing $\mathrm{HH}(\%)$ reported as least significant (LS) means. The predictive odds of the 13 common cultigens were generated by comparisons to 'Maxima'. 'Bold Ruler' was 7.0times more likely to develop $\mathrm{HH}$ in a given year than 'Maxima'.

for $\mathrm{HH}$ incidence. Conversely, cultigens with the highest tissue firmness ('Fusion' and 'LaJuya') were in the lowest $10 \%$ of cultigens for incidence of $\mathrm{HH}$. No trends were found in 2014 for cultigen flesh firmness and $\mathrm{HH}$ incidence.

For the common cultigen set, mean tissue firmness differed across the years $(P>$ 0.0001 ) (Fig. 4), and cultigens with higher tissue firmness values had a lower $\mathrm{HH}$ incidence. Cultigens with an average $\mathrm{HH}$ incidence of $20 \%$ or less, such as 'Crunchy Red', 'Maxima', and 'Captivation', had firmness values of 15 to $16 \mathrm{~N}$. Conversely, tissue firmness was 11 to $12 \mathrm{~N}$ for four of six cultigens with an $\mathrm{HH}$ incidence more than $20 \%$. The mean tissue firmness was negatively correlated to the incidence of $\mathrm{HH}$ $\left(0.88 ; R^{2}=-0.78\right)$. The mean tissue firmness was also negatively correlated to $\mathrm{HH}$ severity $\left(0.62 ; R^{2}=-0.39\right)$. In contrast, $\mathrm{HH}$ incidence and severity was positively correlated $(0.96$; $R^{2}=0.92$ ).

Percentage of unmarketable fruit. When the 13 common cultigens were combined across years, the percentage of unmarketable fruit $(\mathrm{HH}>2)$ differed among cultigens (Fig. 5). However, the percentage of unmarketable fruit for the 13 common cultigens did not differ within 1 year or interact with year $(P>0.05)$. 'Liberty', 'Bold Ruler', and 'Declaration' had the highest percentage of unmarketable fruit $(28.3 \%, 23.3 \%$, and $21.6 \%$, respectively), whereas 'Captivation' had the lowest percentage of unmarketable fruit $(5 \%)$.

Linear regression. In the common cultigen set, linear regression was used to determine the relationship between tissue firmness and $\mathrm{HH}$ incidence (\%) (Fig. 6). Fruit with lower tissue firmness generally had a higher percentage of HH. 'Bold Ruler', 'Liberty', 


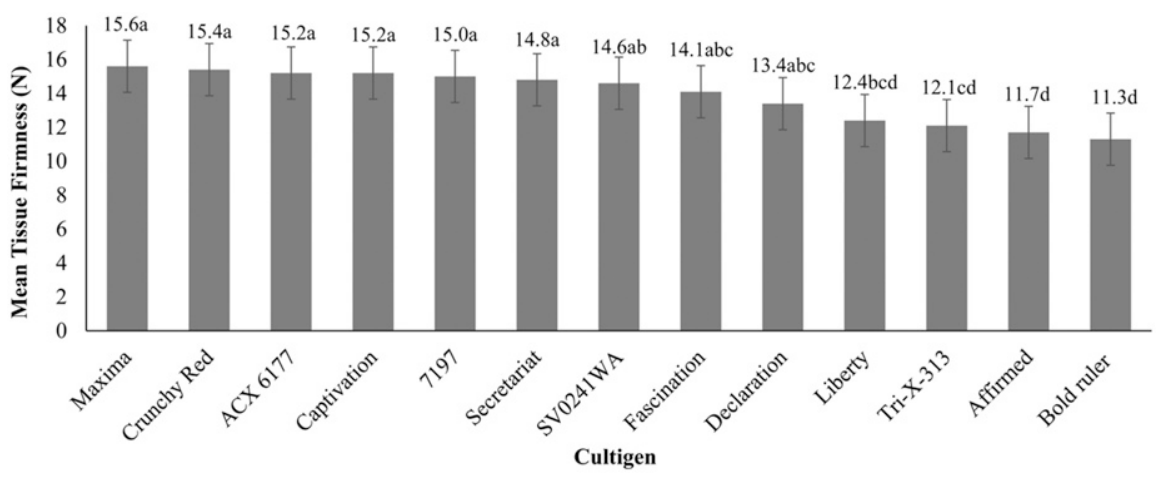

Fig. 4. Watermelon tissue firmness $(\mathrm{N})$ of the common cultigens averaged over the three growing seasons. Differences among cultigens were significant at $P<0.0001$. Tissue firmness $(\mathrm{N})$ is reported as the least significant (LS) means $\pm \mathrm{SD}$, with means separated by the Tukey-Kramer honestly significant difference test $(P \leq 0.05)$. Differences are indicated by different letters.

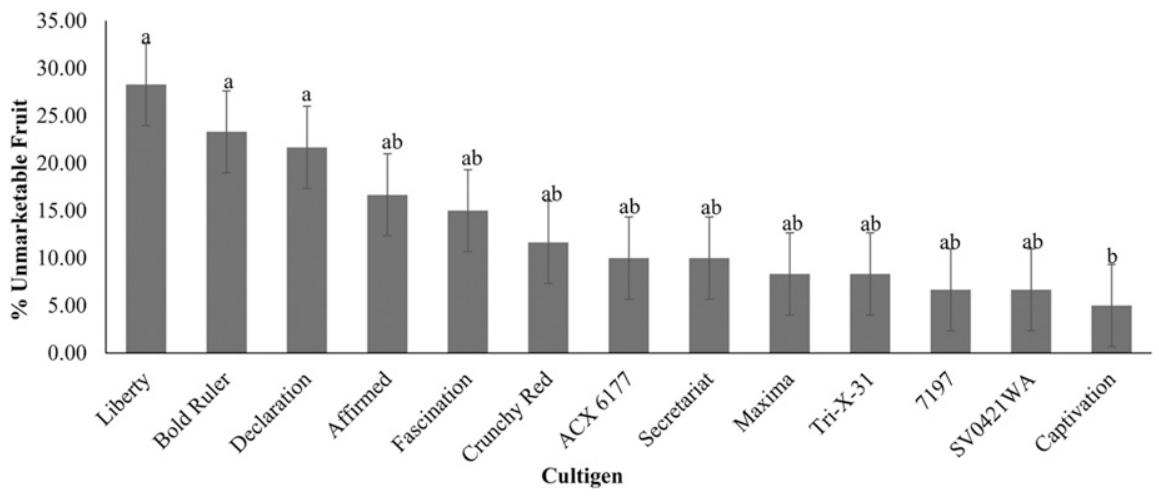

Fig. 5. Percentage (\%) of unmarketable fruit of the 13 common cultigens rated with hollow heart severity $>2$ (considered unmarketable) averaged across the 2012-14 growing seasons. Means were separated by the Tukey-Kramer honestly significant difference test $(P \leq 0.05)$. Differences are indicated by different letters.

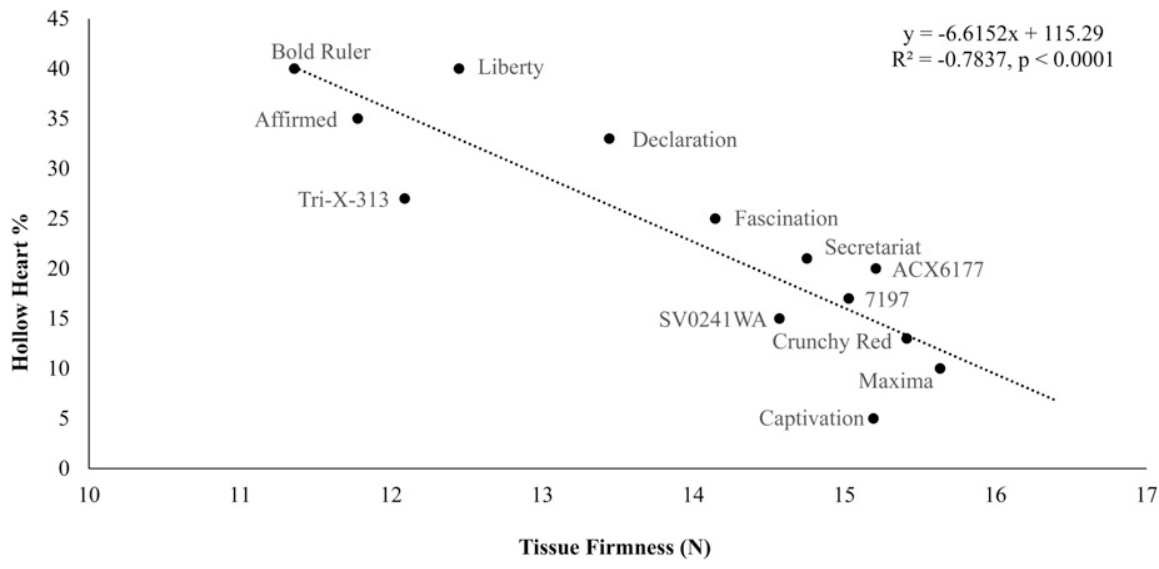

Fig. 6. Linear regression of tissue firmness (N) and incidence of hollow heart (\%) for the 13 common cultigens averaged over the three growing seasons.

and 'Affirmed' had low tissue firmness $(\approx 12$ $\mathrm{N}$ ) and a high probability of developing $\mathrm{HH}$. Conversely, 'Maxima' and 'Captivation' had the lowest probability of developing $\mathrm{HH}$ and higher tissue firmness $(15 \mathrm{~N})$. Using average tissue firmness for 2012-14 in the common cultigen data set, the incidence of $\mathrm{HH}$ was predicted using the following formula: $\mathrm{y}=$ might contribute to this disorder have been explored. Although $\mathrm{HH}$ disorder is found in diploid (seeded) fruit, it is more prevalent in triploid watermelons, which do not produce sufficient viable pollen for fruit set. Peak flowering and pollination of watermelon generally begin at $\approx 2$ to 3 weeks after field transplanting and can continue for an additional 6 weeks (Dittmar et al., 2009; Freeman et al., 2007). Watermelon pistillate flower stigmas are most receptive to pollen from 15 to $26{ }^{\circ} \mathrm{C}$ and senesce within a few hours (Lyu et al., 2019). Pollinators need to visit a triploid flower 16 to 24 times to achieve adequate pollen grain transfer and fruit set (Fiacchino and Walters, 2003; Walters, 2005). Pollen amount and viability, pollinator activity, and pistillate flower receptivity are highly influenced by environmental factors such as rainfall and fluctuations in day and night temperatures, and they contribute to $\mathrm{HH}$ formation (Fiacchino and Walters, 2003; Freeman and Olson, 2007a; McGregor and Waters, 2014). High daytime temperatures $\left(>30{ }^{\circ} \mathrm{C}\right)$ and low morning temperatures $\left(>15{ }^{\circ} \mathrm{C}\right)$ or fluctuations in humidity soon after anthesis can decrease pollen viability (Lyu et al., 2019) and trigger the onset of HH (Stanghellini and Schultheis, 2005).

The use of increased ratios of diploid to triploid plants in this study $(43 \%)$ instead of commercial recommendations (25\%) (Fiacchino and Walters, 2003; Freeman and Olson, $2007 \mathrm{~b}$ ) should have reduced potential pollen deficiencies that may cause HH. In addition, using pollenizers with varied timing of flowering should provide ample pollen throughout production and help reduce $\mathrm{HH}$ incidence. 'Ace' has been reported to have an early flowering date and elongated pollination period, making pollen available for the first female triploid watermelon pistillate flowers as well as those produced later (Sakata Vegetables, 2018). In comparison, 'SP-6' has high pollen release/quantity, thin branches, and small, deep lobed leaves to increase flower visibility to honeybees over an extended period of time (Brusca and Zhang, 2012). Although first bloom dates for male or female flowers were not recorded during the watermelon cultigen evaluations used for this study, male flowering usually begins at 10 to $14 \mathrm{~d}$ posttransplant, and female flowers appear at $21 \mathrm{~d}$ posttransplant (McGregor and Waters, 2014). Average day and night temperatures were similar during the three growing seasons (May-September), although cumulative rainfall was considerably higher in 2013 compared with 2012 and 2014 (Table 1). The large rainfall event in 2013 occurred near the end of the watermelon season, making it less likely to contribute to $\mathrm{HH}$.

Despite the increased ratio of diploid pollenizers, HH still occurred in this study, indicating that some germplasms appear to be more susceptible to HH. In the common cultigen set, 'Liberty', 'Bold Ruler', and 'Affirmed' consistently showed a higher $\mathrm{HH}$ incidence (Fig. 5). These cultigens may 
differ from other cultigens in earliness or lateness of bloom (before adequate pollen is available), or flowers may require more pollen than other cultigens to set fruit and grow normally.

Kano (1993) postulated that when the watermelon placental tissue growth rate (e.g., rapid and irregular fruit growth) exceeds a certain point, tension is imposed on the cells, causing middle lamella separation and $\mathrm{HH}$ disorder. The common cultigen set indicates that a higher $\mathrm{HH}$ incidence is associated with lower tissue firmness (Figs. 4 and 6). Linear regression of the incidence of $\mathrm{HH}$ and mean fruit firmness in the large multiyear cultigen evaluations (data not shown) and the 13 common cultigen set provided negative regression between fruit firmness and $\mathrm{HH}$ incidence (Fig. 6). This suggests that fruit with lower tissue firmness are more susceptible to $\mathrm{HH}$.

Logistic regression. When a dependent variable is considered binomial, logistic regression provides a more robust statistical comparison than linear regression or ANOVA (Lever et al., 2016). Logistic regression was used to determine the incidence of $\mathrm{HH}(\mathrm{HH} \%)$ in the large multiyear data set and common cultigens. Logistic regression was performed separately by year for the large multiyear cultigen set because the cultigens varied considerably across years. No differences were found among the multiyear cultigen evaluations for $\mathrm{HH}$ incidence (Supplemental Table 3), probably because of the high amount of variation within and across replicates. A difference was observed among cultigens in $2012(P<0.003)$, but there was no difference in $2013(P<0.300)$ or $2014(P<0.200)$. Cultigen differences in 2012 likely occurred because there was a higher incidence of $\mathrm{HH}$ in 2012 than in the other years.

The 13 common cultigen data set was analyzed by year and across years with data combined. When combining data across years, the common cultigens showed differences in $\mathrm{HH}$ incidence (Table 2). Logistic regression for the common cultigens also provided the predictive odds of developing $\mathrm{HH}$ when compared with 'Maxima', which was one of the cultigens that was least likely to develop HH. The predicative odds indicated that 'Bold Ruler' and 'Liberty' were 7-times and 6.9-times more likely, respectively, to develop HH than 'Maxima', which had one of the lowest odds of developing this disorder. 'Captivation' was the only cultivar with lower odds than 'Maxima' and was 0.4 -times as likely to develop $\mathrm{HH}$ as 'Maxima' (Table 2).

\section{Conclusion}

Using watermelon cultigen evaluation data collected over 3 years and logistic regression, cultigen tendencies were found for $\mathrm{HH}$ despite the unpredictable nature of this disorder. Tissue firmness was negatively correlated with $\mathrm{HH}$ incidence according to all analyses, indicating that triploid cultigens with lower tissue firmness may be more likely to develop HH. This information provides a means for cultigen screening for $\mathrm{HH}$ even in seasons when $\mathrm{HH}$ is not prevalent. Applying logistic regression to $\mathrm{HH}$ incidence and tissue firmness yielded the predictive odds/probability for watermelon cultigens to develop HH. This approach indicated that cultigens can be used as benchmarks for high ('Bold Ruler', 'Liberty', and 'Affirmed') and low incidences ('Maxima' and 'Captivation') during cultigen studies screening for $\mathrm{HH}$ incidence.

\section{Literature Cited}

Brusca, J. and X. Zhang. 2012. United States patent: Watermelon pollenizer SP-6. Patent no. US $8,212,118$ B1. <https://patentimages.storage. googleapis.com/0f/d4/dd/c7678b0b5e70ca/ US8212118.pdf>.

Coolong, T. 2015. 2014/2015 University of Georgia vegetable crops research report. UGA Cooperative Extension Annual Publication, p. 61-69. $<$ https://secure.caes.uga.edu/extension/publications/ files/pdf/AP\%20115_2.PDF>

Diezma-Iglesias, B., M. Ruiz-Altisent, and P. Barreiro. 2004. Detection of internal quality in seedless watermelon acoustic impulse response. Biosyst. Eng. 88(2):221-230, doi: 10.1016/j.biosystemseng.2004.03.007.

Dittmar, P., M.W. Monks, and J.R. Schultheis. 2009. Maximum potential vegetative and floral production and fruit characteristics of watermelon pollenizers. HortScience 44(1):59-63, doi: 10.21273/HORTSCI.44.1.59.

Elmstrom, G.M. and P.L. Davis. 1981. Sugars in developing and mature fruits of several watermelon cultivars. J. Amer. Soc. Hort. Sci. 106(3):330-333.

Fiacchino, D.C. and S.A. Walters. 2003. Influence of diploid pollenizer frequencies on triploid watermelon quality and yields. HortTechnology 13(1):58-61, doi: 10.21273/HORTTECH. 13.1.0058

Freeman, J. and S. Olson. 2007a. Characteristics of watermelon pollinizer cultivars for use in triploid production. Intl. J. Veg. Sci. 13(2):73-78, doi: 10.1300/J512v13n02_07.

Freeman, J. and S. Olson. 2007b. Competitive effect of in-row diploid watermelon pollinizers on triploid watermelon yield. HortScience 42(7):1575-1577, doi: 10.21273/HORTSCI. 42.7.1575.

Freeman, J., G.A. Miller, S.M. Olson, and W.M. Stall. 2007. Diploid watermelon pollenizer cultivars differ with respect to triploid watermelon yield. HortTechnology 17(4):518-523, doi: 10.21273/HORTSCI.42.7.1575.

Guan, W. 2018. Hallowheart of watermelons. Purdue Agriculture. <https://ag.purdue.edu/btny/ ppdl/Pages/POTW2018/POTW09042018. $\operatorname{aspx}>$.

Johnson, G. 2014. These beautiful watermelon patterns are driving everyone crazy. $<\mathrm{https} / /$ www.boredpanda.com/weird-watermelonsbeautiful-hollow-heart/s.

Johnson, G. 2015. Researcher finds potential cause of hollow heart disorder in watermelon. PhysOrg. <https://phys.org/news/ 2015-06-potential-hollow-heart-disorderwatermelons.html>.

Johnson, G. 2017. Seedless watermelon trials 2017. Weekly crop update. UD Cooperative Extension. $\quad<\mathrm{https}: / /$ sites.udel.edu/weeklycropupdate/?p=11482>.

Kano, Y. 1993. Relationship between the occurrence of hollowing in watermelon and the size and the number of fruit cells and intercellular air space. J. Jpn. Soc. Hort. Sci. 62(1):103-112, doi: $10.2503 /$ jjshs.62.103.
Kleiss, S. 1981. Soils of Central Crops Research Station: Their technical and usability classification. Soil Science Society of North Carolina. $<$ http://agronomy.agr.state.nc.us/sssnc/index. htm>.

Lever, J., M. Krzywinski, and N. Altman. 2016. Logistic regression: Regression can be used on categorical responses to estimate probabilities and to classify. Nat. Methods 13(7):541-548, doi: 10.1038/nmeth.3904.

Lyu, X., S. Chen, N. Liao, J. Liu, J. Yang, and M. Zhang. 2019. Characterization of watermelon anther and its programmed cell death- associated events during dehiscence under cold stress. Plant Cell Rpt 38(12):1551-1561, doi: 10.1007/s00299-019-02466-2.

McGregor, C. and V. Waters. 2014. Flowering patterns of pollenizer and triploid watermelon cultivars. HortScience 49(6):714-721, doi: 10.21273/HORTSCI.49.6.714.

Pisanty, G., O. Afik, E. Wajnberg, and Y. Mandelik. 2016. Watermelon pollinators exhibit complementary in both visitation rate and single-visit pollination. J. Appl. Ecol. 53(2):360-370.

Sakata Vegetables. 2018. 'Ace Plus'. Sakata Seed America $\odot .<$ https://sakatavegetables.com/ vegetable/watermelon/ace-plus/>.

Schultheis, J.R. and B. Thompson. 2012. Watermelon cultivar trials NCSU, no. 203, p. 1-55. $<$ https://cucurbits.ces.ncsu.edu/wp-content/uploads/2017/03/2012-WM-Cultivar-BookletFinal.pdf? fwd $=$ no $>$.

Schultheis, J.R. and B. Thompson. 2013. Watermelon cultivar trials. NCSU, no. 207, p. 1-56. $<$ https://cucurbits.ces.ncsu.edu/wp-content/uploads/2017/03/2013-WM-Cultivar-EvaluationBooklet.pdf? fwd $=$ no $>$.

Schultheis, J.R. and B. Thompson. 2014. North Carolina State University watermelon cultivar trials, no. 210 , p. 1-39. <https://gates.ces.ncsu.edu/wp-content/uploads/2015/01/NCSUWatermelon-Cultivar-Booklet_2014.pdf? fwd $=$ no.

Seminis Seeds. 2019. Agronomic spotlight. Hollow heart of watermelon. <https://seminisus.s3.a mazonaws.com/app/uploads/2019/11/5070_ SE_S1_Hollow-Heart-of-Watermelon.pdf>.

Soteriou, G.A., A.S. Siomos, D. Gerasopoulous, Y. Rouphael, S. Georgiadou, and M.K. Kyriacou. 2017. Biochemical and histological contributions to textural changes in watermelon fruit modulated by grafting. J. Food Chem. 237(1):133-140, doi: 10.1016/j.foodchem.2017.05.083.

Stanghellini, M. and J. Schultheis. 2005. Genotype variability in staminate flower and pollen grain production of diploid flowers. HortScience 40(3):752-755, doi: 10.21273/ HORTSCI.40.3.752.

Tlili, I., C. Hdider, M. Lenucci, S. Ilahy, and G. Dalessandro. 2011. Bioactive compounds and antioxidant activities during fruit ripening of watermelon cultivars. J. Food Compos. Anal. 34(7):923-928, doi: 10.1016/j.jfca. 2011.03.016.

Walters, A. 2005. Honey bee pollination requirements for triploid watermelon. HortScience 40(5):1268-1270, doi: 10.21273/HORTSCI. 40.5.1268.

USDA. 2006. US standards for grades of watermelon. Agricultural Marketing Services, Fruit and Vegetable Program, p. 1-11.

USDA. 2019. Specialty crop market news. Seeded and seedless watermelon production. $<\mathrm{https}: / /$ www.ams.usda.gov/mnreports/wa_fv456.txt>. 


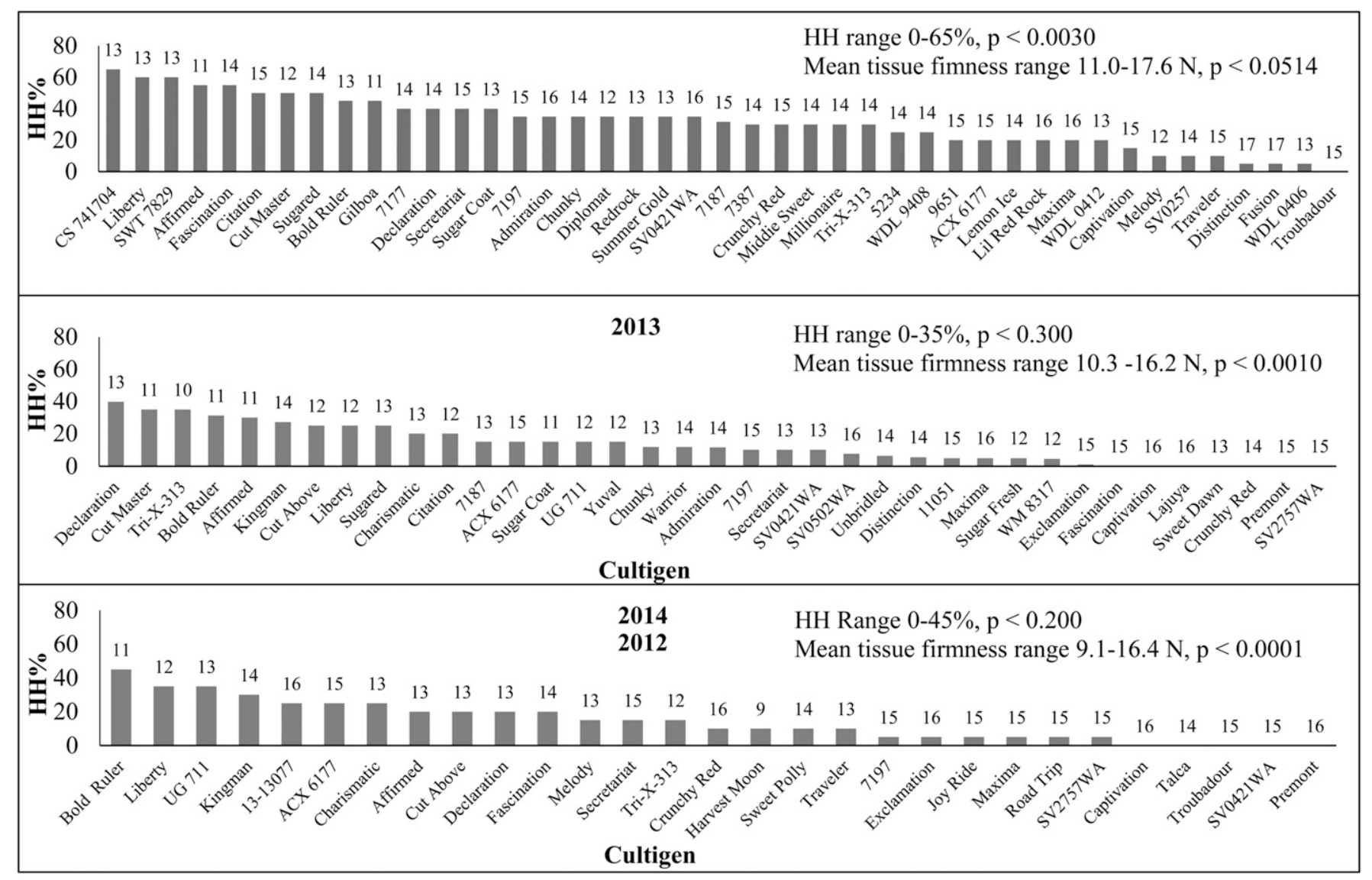

Supplemental Fig. 1. Percentage (\%) of hollow heart (HH) with mean tissue firmness in newtons $(\mathrm{N})$ reported as least significant (LS) means above the bars in 2012, 2013, and 2014. Differences were found in fruit mean tissue firmness during the 2012, 2013, and 2014 evaluations $(P \leq 0.05)$. The HH incidence among cultigens was different only in 2012; no other differences in the incidence or severity occurred.

Supplemental Table 1. Watermelon cultigen names of the 13 common cultigens used in 2012, 2013, and 2014, and their relative fruit characteristics.

\begin{tabular}{lc}
\hline Cultigen name & Fruit description \\
\hline ACX 6177 & Indistinct medium-wide green stripes; long, round fruit shape; medium fruit size \\
SV0241 & Indistinct medium to dark green stripes on light green background; long and round to blocky shape; medium to large fruit size \\
Indistinct medium to dark green stripes on medium green background; short and blocky to oval fruit shape; variable size; & distinct red flesh \\
Affirmed & Indistinct medium-wide dark green strips on light green background; short, blocky shape; medium to large fruit size \\
Bold Ruler & Indistinct medium-wide medium to dark green stripes on light green background; short and blocky to oval shape; medium to \\
large fruit size & Indistinct medium-wide medium to dark green stripes, light green background; short, blocky shape; medium to large fruit \\
Captivation & size; excellent rind/flesh delineation; hard core \\
Indistinct medium-wide medium green stripes on light green background; small fruit are round and large are elongated; fruit & are mainly large; very thick fruit rind \\
Crunchy Red & Indistinct medium-wide dark green strips on light green background; uniform oval, blocky fruit; uniform medium to large \\
Declaration & size; indistinct rind delineation \\
Fascination & Indistinct medium-wide dark green stripes on light green background; oval, blocky shape; medium to large size; very dark red \\
flesh & Indistinct medium-wide medium to dark green stripes on light green background; oval to short blocky fruit with small fruit \\
Liberty & size more round in shape; generally medium to large fruit size \\
Maxima & Distinct medium-wide very dark green stripes; short oval to round shape; medium to large fruit size \\
Secretariat & Indistinct medium-wide medium to dark green stripes on light green background; blocky fruit with uniform shape; medium to \\
large size fruit; indistinct rind flesh delineation; good red flesh color
\end{tabular}


Supplemental Table 2. Fungicide, insecticide, and miticide programs used for watermelon in 2012, 2013 and 2014.

\begin{tabular}{|c|c|c|c|c|c|}
\hline \multicolumn{2}{|r|}{2012} & \multicolumn{2}{|r|}{2013} & \multicolumn{2}{|r|}{2014} \\
\hline Pesticide & Fungicide & Pesticide & Fungicide & Pesticide & Fungicide \\
\hline Esenvalerate 'Asana' & Copper hydroxide 'Kocide' & Bifenthrin 'Fan Fare' & Copper hydroxide 'Kocide' & Bifenthrin 'Fan Fare' & Copper hydroxide 'Kocide' \\
\hline $\begin{array}{l}\text { Permethrin 'Perm } \\
\text { Up' }\end{array}$ & $\begin{array}{l}\text { Propamocarb 'Previcur } \\
\text { Flex' }\end{array}$ & Endosulfan 'Phaser' & $\begin{array}{l}\text { Propamocarb 'Previcur } \\
\text { Flex' }\end{array}$ & Carabaryl 'Sevin' & $\begin{array}{l}\text { Propamocarb 'Previcur } \\
\text { Flex' }\end{array}$ \\
\hline Bifenthrin 'Sniper' & Mancozeb 'Penncozeb' & & Mancozeb 'Penncozeb' & & Mancozeb 'Penncozeb' \\
\hline
\end{tabular}


Supplemental Table 3. Logistic regression showing the incidence of hollow heart (HH) among 2012, 2013, and 2014 seedless watermelon evaluations.

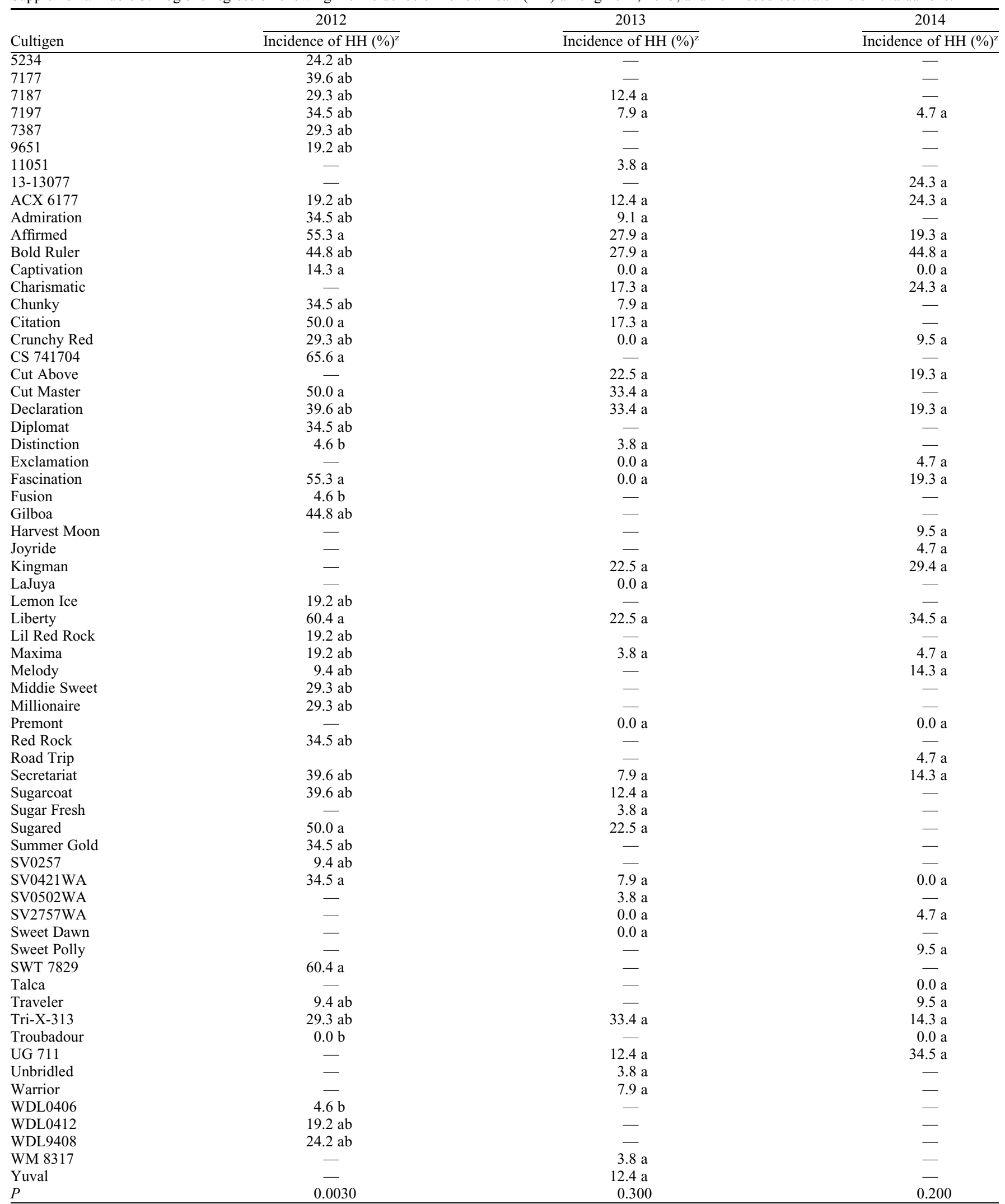

${ }^{\mathrm{z}}$ Odds of developing HH (\%) reported as least significant (LS) means $(\alpha=0.05)$. Means were separated by the Tukey-Kramer honestly significant difference test. 